\title{
Signaling pathway cross talk in Alzheimer's disease
}

\author{
Juan A Godoy ${ }^{1}$, Juvenal A Rios', Juan M Zolezzi ${ }^{2}$, Nady Braidy ${ }^{3}$ and Nibaldo C Inestrosa ${ }^{1,3^{*}}$
}

\begin{abstract}
Numerous studies suggest energy failure and accumulative intracellular waste play a causal role in the pathogenesis of several neurodegenerative disorders and Alzheimer's disease (AD) in particular. AD is characterized by extracellular amyloid deposits, intracellular neurofibrillary tangles, cholinergic deficits, synaptic loss, inflammation and extensive oxidative stress. These pathobiological changes are accompanied by significant behavioral, motor, and cognitive impairment leading to accelerated mortality. Currently, the potential role of several metabolic pathways associated with $A D$, including Wnt signaling, 5' adenosine monophosphate-activated protein kinase (AMPK), mammalian target of rapamycin (mTOR), Sirtuin 1 (Sirt1, silent mating-type information regulator 2 homolog 1), and peroxisome proliferator-activated receptor gamma co-activator 1-a (PGC-1a) have widened, with recent discoveries that they are able to modulate several pathological events in AD. These include reduction of amyloid- $\beta$ aggregation and inflammation, regulation of mitochondrial dynamics, and increased availability of neuronal energy. This review aims to highlight the involvement of these new set of signaling pathways, which we have collectively termed "anti-ageing pathways", for their potentiality in multi-target therapies against AD where cellular metabolic processes are severely impaired.
\end{abstract}

Keywords: Neurodegeneration, Cognitive decline, Neuronal network failure, Reactive oxygen species, Alzheimer's disease

\section{Lay abstract}

Alzheimer's disease $(\mathrm{AD})$ is characterized by the progressive loss of cholinergic neurons leading to dementia. Deciphering the molecular basis underlying this multifactorial neurodegenerative disorder remains a significant challenge. Increased oxidative stress and misfolded protein formations are the basis of AD. Recently, the several new cellular signaling pathways have been implicated in the pathobiology of $\mathrm{AD}$. These include Wnt signaling, 5' adenosine monophosphate-activated protein kinase (AMPK), mammalian target of rapamycin (mTOR), Sirtuin 1 (Sirt1, silent mating-type information regulator 2 homolog 1), and peroxisome proliferator-activated receptor gamma co-activator 1- $\alpha$ (PGC-1 $\alpha)$. These new signaling pathways may provide new therapeutic targets to slow down or prevent the development of $\mathrm{AD}$.

\footnotetext{
* Correspondence: ninestrosa@bio.puc.cl

${ }^{1}$ Centro de Envejecimiento y Regeneración (CARE); Departamento de Biología Celular y Molecular; Facultad de Ciencias Biológicas, Pontificia Universidad Católica de Chile, Av. Alameda 340, Santiago, Chile

${ }^{3}$ Center for Healthy Brain Ageing, School of Psychiatry, Faculty of Medicine, University of New South Wales, Sydney, Australia

Full list of author information is available at the end of the article
}

\section{Introduction}

Alzheimer's disease (AD) is a debilitating neurodegenerative disorder characterized by the progressive loss of cholinergic neurons, leading to the onset of severe behavioral, motor and cognitive impairments. In order to establish the criteria that would accurately define AD, patients with senile dementia were traditionally excluded since, despite its similarity, senile dementia was generally considered an age-associated phenomenon, and not a true disease. However, since extracellular amyloid $\beta(A \beta)$ plaques and intracellular neurofibrillary tangles (NFTs) containing hyper-phosphorylated tau, are frequently present in the brain of patients with senile dementia, investigators eventually expanded the definition of $\mathrm{AD}$ to also include those with senile dementia, plaques and tangles (Figure 1) [1].

Energy demands and calcium fluctuation within neuronal synapses are the prerequisite of neuronal communication; to meet this process, the mitochondria are enriched in synapses for site-directed energy provision and calcium homeostasis. Reduced energy metabolism, 

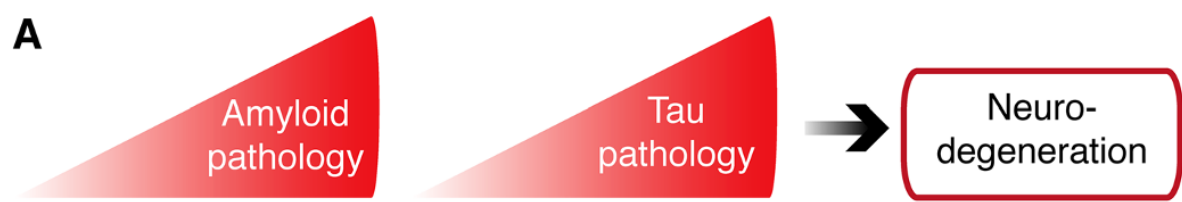

B

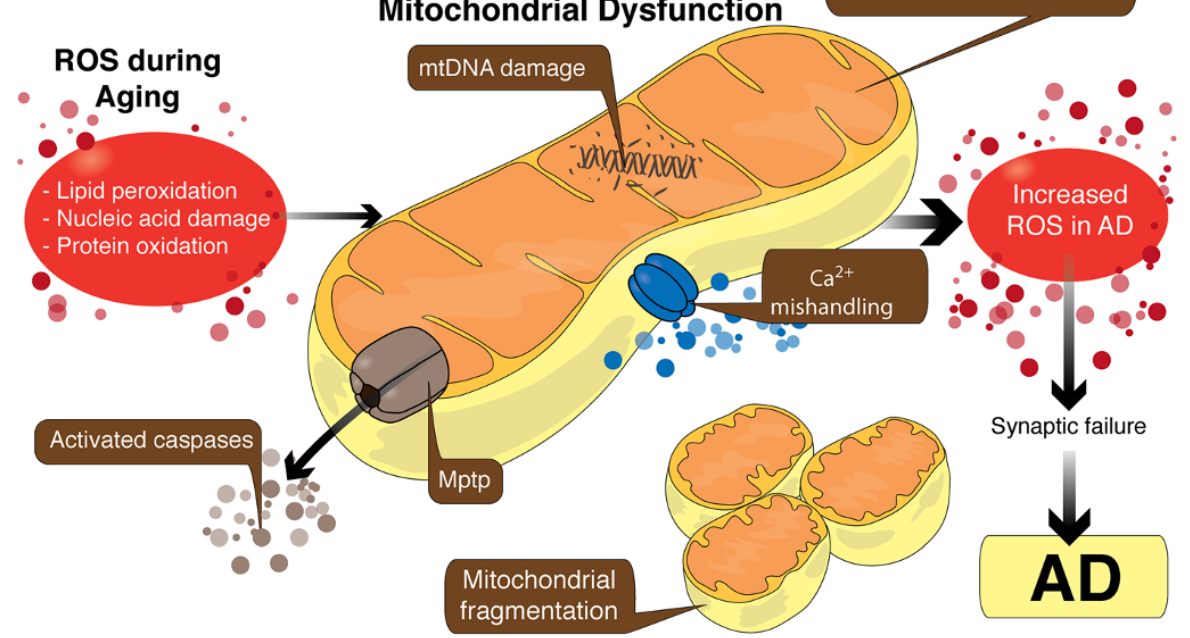

Figure 1 Hallmarks of AD, progression of the disease and mitochondrial dysfunction. $\mathbf{A}$ : The diagram shows the hallmarks in AD. B: The multiple pathogenic mechanisms contributing to the pathological hallmarks of AD consist of increased of ROS production, AB-induced mitochondrial dysfunction, and apoptosis due to impairment of mitochondrial $\mathrm{Ca}^{2+}$ handling ability, altered $\mathrm{Ca}^{2+}$ homeostasis, increased mitochondrial permeability transition pore opening, and promotion of cytochrome $c$ release. A $\beta$ inhibits protein import inside the mitochondria. APP also alters $\mathrm{Ca}^{2+}$ homeostasis leading to apoptosis. Mitochondrial DNA mutations and mitochondrial DNA damage are also involved in the pathogenesis of AD, and are associated with synaptic and neuronal loss, amyloid plaques, and NFTs. Perturbed cerebral energy metabolism plays a central role in multiple pathogenic cascades of AD. Abbreviations: AD, Alzheimer's disease; $\mathrm{Ca}^{2+}$, calcium; Mptp, mitochondrial permeability transition pore; ROS, reactive oxygen species.

particularly related to low levels of glucose, in the diseased brain is one of the best documented metabolic abnormalities in $\mathrm{AD}$. In fact, the decline in baseline glucose metabolism is viewed as a sensitive measure, useful for monitoring change in cognition and functionality in $\mathrm{AD}$. Deficits in mitochondrial function and increased $A \beta$ accumulation in synapses lead to reduced synaptic activity and consequent neuronal damage. Such synaptic alteration and mitochondrial dysfunction have been observed in many neurodegenerative disorders including $\mathrm{AD}$. The normal physiological function of the mitochondria is dependent upon their intact structure to maintain the electrochemical gradient. Structurally damaged mitochondria, as evidenced by partial or near complete loss of the internal structure and cristae, are abundant and represent a prominent feature in dystrophic neurons in postmortem $A D$ brains [2]. On the other hand, calcium $\left(\mathrm{Ca}^{2+}\right)$ mishandling has been reported in peripheral cells isolated from AD patients, with the endoplasmic reticulum (ER) developing calcium overload due to reduced calcium uptake (Figure 1) [3].

Mitochondria are highly metabolic organelles that combine nutrient sensing and growth signaling pathways to regulate health span and longevity by maintaining energy production and $\mathrm{Ca}^{2+}$ homeostasis, and reducing apoptosis. Genetic approaches have identified several signaling pathways which represent critical modifiers of mitochondrial function. These pathways have been shown to increase the transcription of important mitochondrial genes following exposure to oxidative and inflammatory insult within the cell. Among these signaling pathways are the Wnt signal transduction pathways, $5^{\prime}$ adenosine monophosphateactivated protein kinase (AMPK), mechanistic target of rapamycin (mTOR) complexes, and activation of the Sirtuin 1 (silent mating-type information regulator 2 homolog 1)/peroxisome proliferator-activated receptor gamma co-activator $1-\alpha($ Sirt1/PGC-1 $\alpha)$ axis.

In this review, we will focus on already published evidence that allows, based in our own experience, to propose a potential connection between several mechanisms already described as neurodegenerative/ADrelated and how these signaling pathways will contribute to $\mathrm{AD}$. We consider that a greater understanding of the molecular basis of these pathways and how they interact within the cell will foster efforts to slow down or attenuate metabolic deficits that are observed in AD. 
Role of Wnt signaling in neuronal synaptogenesis and AD The Wnt signaling pathway is involved in several key cellular processes associated with cellular proliferation, differentiation, adhesion, survival, and apoptosis in several catabolic and anabolic cells, including neurons and glial cells which are the key resident cells of the Central Nervous System (CNS) [4,5]. Wnt proteins are a family of secreted cysteine-rich glycosylated protein that are named after the Drosophila protein "wingless" and the mouse protein "Int-1" [4]. Currently, 19 of the $24 \mathrm{Wnt}$ genes expressing Wnt protein have been identified in humans, while $80 \mathrm{Wht}$ target genes have been indentified from genetic studies in human, mice, Drosophila, Xenopus, and Zebrafish populations [4,5]. Wnt binds to Frizzled $(\mathrm{Fz})$ transmembrane receptors located on the cell surface leading to the induction of at least three distinct downstream signaling pathways [5]. The first is known as the canonical $W n t$ pathway which regulates gene transcription through $\beta$-catenin, also called $W n t / \beta$ catenin. The second, is the non-canonical pathway modulates by intracellular $\mathrm{Ca}^{2+}$ release, also called $\mathrm{Wnt} / \mathrm{Ca}^{2}$ ${ }^{+}$, and the third one, the Wnt cell polarity, in which the Jun N-terminal kinase (JNK) plays a role, also called the Wnt/PCP-JNK pathway [6-8].

\section{Wnt Signaling protects synaptic integrity from $A \beta$ toxicity}

Numerous studies have shown that Wnt signaling components are altered in AD: (a) among the Wnt components that are affected in $\mathrm{AD}$, it was shown that $\beta$-catenin levels are reduced in $\mathrm{AD}$ patients carrying presenilin-1 (PS1)-inherited mutations [9]; (b) exposure of cultured hippocampal neurons to $A \beta$ results in the inhibition of canonical Wnt signaling [10,11]; (c) Dickkoff-1 (Dkk1) a $W n t$ antagonist is induced by the $\mathrm{A} \beta$ protein in hippocampal neurons [12]; and it is elevated in post-mortem brain samples from $\mathrm{AD}$ patients and brains from transgenic $\mathrm{AD}$ animal models [13,14]; (d) Dkk3, highly related to Dkk1, is elevated in plasma and cerebrum spinal fluid from $A D$ patients [15]; (e) apo-lipoprotein E (apoE\&4), a risk AD factor, inhibits canonical Wht signaling [16]; (f) a common genetic variation within the low-density lipoprotein receptor-related protein 6 (LRP6) lead to disease progression [17]; (g) Dkk1 reversibly reduces the amount of synaptic proteins and the number of active pre-synaptic sites, inducing synaptic disassembly at pre- and postsynaptic sites [18,19]; (h) clustering, a susceptibility factor for lateonset $A D$, regulates $A \beta$ amyloid toxicity via Dkk1-driven induction of the non-canonical $W n t / P C P-J N K$ pathway, which contributes to tau phosphorylation and cognitive impairment [20].

Synaptic failure is an early event in AD, and soluble $A \beta$ oligomers are proposed to be responsible for the synaptic pathology that occurs prior to plaque deposition and neuronal death [21]. The non-canonical Wnt-5a ligand prevents the decrease in the amplitude of excitatory postsynaptic currents induced by $\mathrm{A} \beta$ oligomers, indicating that this ligand prevents the synaptic damage triggered by $\mathrm{A} \beta$ [22]. Wnt-5a prevents the decrease in the PSD-95 postsynaptic clusters through the Wnt/PCP$J N K$ pathway. However, Wnt-5a also stimulates the trafficking of $\mathrm{GABA}_{\mathrm{A}}$ and $\mathrm{NMDA}$ receptors to the neuronal surface [23,24], the development of dendritic spines [25] and protects neuronal mitochondria from $A \beta$ oligomers [26], through the activation of the $W n t / C a^{2+}$ pathway. More recent studies, using small Wnt molecules to activate both canonical and non-canonical Wht signaling in vivo, enhances cognition in adult mice and reverses cognitive deficits and LTP in the APPswe/PS-1 transgenic model of $\mathrm{AD}$ [27]. These studies support the idea that alterations in the Wnt signaling pathway, both the canonical (Wnt/ $/$-catenin) and the non-canonical (Wnt/ $P C P$ and $\mathrm{Wnt} / \mathrm{Ca}^{2+}$ ) are involved in the modulation of synaptic development, as well as, in the progression of $\mathrm{AD}[28]$.

Finally, the activation of several signaling pathways that cross talk with the Wnt pathway, including the nicotinic and muscarinic ACh receptors, peroxisome proliferator-activated receptor (PPAR) $\alpha$ and $\gamma$, antioxidants, and anti-inflammatory pathways, support the neuroprotective potential of the Wnt signaling cascade in $\mathrm{AD}$ [29-31].

\section{Cholinergic system and Wnt Signaling cross-talk: ancient and new strategy}

The "cholinergic hypothesis" of $\mathrm{AD}$, which was developed after disturbances were found in the metabolism of acetylcholine in postmortem AD brains [32], states that there is a loss of cholinergic neurons in the basal forebrain and that the impairment of cognitive functions and the behavioral disturbances observed in patients with $\mathrm{AD}$ are due, in part, to cortical deficiencies in cholinergic neurotransmission. The decrease of cholinergic neurons leads to the alteration of several proteins in the cholinergic system, such as decreased activity of acetylcholinesterase (AChE) and cholineacetyl transferase [32]. We have previously shown that a macromolecule found in the synapses interacts with $A \beta$ to form a complex which alters the normal synaptic function in hippocampal neurons [33,34]. Additionally, our group has also demonstrated that $\mathrm{A} \beta-\mathrm{AChE}$ complexes were more neurotoxic than those of $A \beta$ alone, depending on the level of AChE [34], suggesting that AChE may plays a key role in the neurodegenerative changes observed in the $\mathrm{AD}$ brain. Interestingly, hyperforin, a phytochemical drug which modulates acetylcholine release in the CNS, [34], is able to prevent the $A \beta$-induced spatial memory impairments and $\mathrm{A} \beta$ neurotoxicity in vivo $[35,36]$. Moreover, tetrahydrohyperforin (THH), a semi-synthetic 
derivative of hyperforin, restores brain AChE activity, reduces the levels of cholinergic markers associated with amyloid plaques, oxidative stress, and apoptosis, and protects cholinergic neurons in a double transgenic mouse model of AD [36,37].

A recent study has shown that a Wnt signaling pathway may be involved in maintaining synaptic strength in the CNS by modulating the translocation of a subset of acetylcholine receptors (AChRs) to synapses [38]. In Caenorhabditis elegans, mutations in the Wnt ligand, CWN-2, the Fz receptor, LIN-17, the Ror receptor tyrosine kinase, CAM-1, and the DSH cytoplasmic phosphoprotein, DSH-1 (involved in both canonical and non-canonical Wnt signaling) lead to synaptic accumulation of the AChR, a mutant $\alpha_{7-n A C h}$ receptor (ACR-16/ $\alpha 7$ ), impaired synaptic function, and trigger significant behavior deficits $[37,38]$. Results of this study suggest that synaptic plasticity is mediated, at least partly, by Wnt signaling.

\section{Reducing oxidative stress by Wnt signaling activation}

A $\beta$ accumulation is believed to plays a key role in the cognitive deficits observed in $\mathrm{AD}$ patients. There is evidence relating the etiopathology of the disease with free radicals [39]. Through in vitro experiments it has been shown that one of the neurotoxicity mechanism of $\mathrm{A} \beta$ peptides is through oxidative stress, and inhibitors of catalase-A $\beta$ interactions protect from $A \beta$ toxicity [40]. Moreover, the enhancement of the oxidative state by the in vivo depletion of vitamin $\mathrm{E}$ has been shown to result in an increased amount of $A \beta$ by the inhibition of it clearance from the brain [41]. Previously, we have shown that the peroxisomal proliferation, simultaneously with an increase in catalase, is able to protects against the neurotoxicity of $A \beta$ in cultured rat hippocampal neurons, leading to significant improvements in spatial memory, lower levels of $A \beta$ aggregates, reduced glial activation, decreased tau phosphorylation, and increased postsynaptic proteins and long-term potentiation (LTP) [42].

Wnt signaling may also confer neuroprotection against oxidative stress in AD. Wnt1 overexpression has been shown to protect neurons against $A \beta$-mediated oxidative stress, and oxidative DNA damage in primary hippocampal murine neurons [4]. Reduced Wnt activity may also increase the vulnerability of neuronal cells to oxidative insult [43]. In $\mathrm{AD}, \mathrm{A} \beta$ toxicity can induce the expression of glycogen synthase kinase 3 (GSK-3 $\beta$ ), a serine/threonine protein kinase which phosphorylates $\beta$-catenin, and thus leading to its depletion $[5,18]$. Also, reduced production of $\mathrm{A} \beta$ can occur in response to increased PKC activity which is regulated by the $W n t$ pathway $[5,18]$. Overexpression of DSH-1 and DSH-2 has been shown to inhibit GSK-3 $\beta$ mediated phosphorylation of tau protein, thus preventing the formation of NFTs (one of the main pathological hallmarks of AD), and increasing neuroprotection [44].

\section{Cross-talk between AMPK and mTOR pathway}

AMPK is a heterotrimeric protein kinase complex expressed widely in most cell and tissue types. The primary function of AMPK is to act as a sensor of intracellular ATP levels and is coupled to phosphorylation of downstream substrates of ATP producing pathways [45]. The regulation of AMPK involves two upstream pivotal enzymes: Serine/threonine kinase 11 (STK11) also known as liver kinase $\mathrm{B} 1$ (LKB1), the $\mathrm{Ca}^{2+} / \mathrm{CaM}$-dependent protein kinase kinase $\beta(\mathrm{CaMKK} \beta)$ and also other stimulus like as nitric oxide (NO) [46]. AMPK is returned to its inactive form by dephosphorylation mediated by specific phosphatases (PPase) [47]. AMPK possesses several downstream targets including enzymes associated with glycolytic pathways and lipolysis, and even "master energy regulators" [48], such as the PPAR $\gamma$ coactivator- $1 \alpha$ (PGC-1 $\alpha$ ), which triggers mitochondrial biogenesis via Sirt1-mediated de-acetylation in response to AMPK activation (Figure 2) [49]. AMPK also directly phosphorylates several sites of the transcription factor, Forkhead box O3 (FOXO3), activating transcription of several genes, including some associated with resistance to oxidative stress [50]. Additionally, AMPK inhibits protein synthesis by direct phosphorylation of Raptor and ULK1, a novel serine/threonine kinase and subunit of the mTORC1 complex, triggering autophagy to recycle amino acids and other cell components during cellular starvation (Figure 2) $[51,52]$. In neuronal cells, increased mTOR activity results in several stimuli, including BDNF, leptin and $\mathrm{Ca}^{2+}$ influx, and contributes to the maintenance of synaptic plasticity through regulation of protein synthesis required for the late-phase of long-term potentiation (LTP) [53]. Therefore AMPK functions as a "master of master cell physiology", and pharmacological modulation represents an attractive therapeutic target for many age-related disorders, such as neurodegenerative diseases and $\mathrm{AD}$ in particular.

\section{Deciphering the role of AMPK-mTOR in AD}

Currently the role of AMPK and mTOR in the development and progression of $\mathrm{AD}$ is poorly understood, and recent studies have provided evidence that $A M P K$ and mTOR are main targets for deregulations in AD $[54,55]$. Controversially, in vitro models have shown that AMPK activation inhibits tau phosphorylation in rat cortical neurons [56], while others confirmed that AMPK could phosphorylate tau at several sites (including Thr231 and Ser396/404), and interrupts the binding of tau to microtubules $[57,58]$. On the other hand, several studies have shown that AMPK activation represses amyloidogenesis in neurons [59]. Additionally, AMPK activation decreases mTOR signaling and enhances autophagy and lysosomal degradation of $A \beta$ [60-63]. Nevertheless, a recent study demonstrated that metformin, an oral antidiabetic drug in 


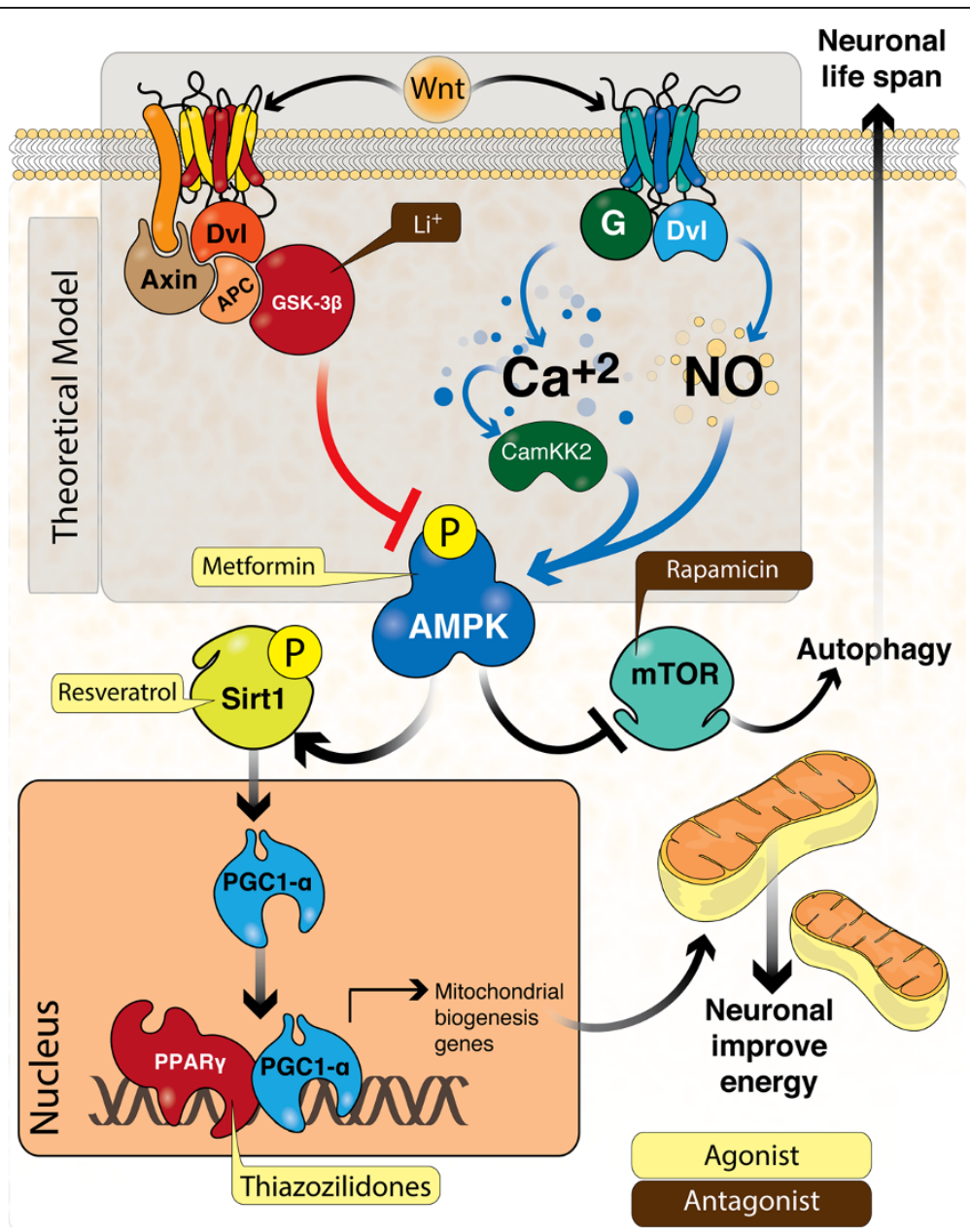

Figure 2 Interplay between Wnt signaling and other anti-ageing pathways. In this scheme we show the integration and interaction of multiple signaling pathways: the first line (top) shows a Wnt ligand, binding Frizzled receptor and activated canonical and non-canonical Wnt signaling. The canonical pathway (left) leads to GSK3ß inhibition. AMPK activation is known to inhibit by GSK3 $\beta$. The non-canonical pathway (right) increases intracellular $\mathrm{Ca}^{2+}$ levels. Nitric oxide (NO), a second messenger, is known to directly activate AMPK. AMPK is also activated by $\mathrm{Ca}^{2+}$ through CaMKK2. Therefore, AMPK activation by the Wnt pathway represents a hypothetical concept ("theoretical model" in transparent gray box). In the second line, AMPK leads to activation of Sirt1 (right). Sirt1 de-acetylates PGC-1a, and this transcription factor translocates to the nucleus and interacts with PPARy heterodimerization to enhance the expression of mitochondrial biogenesis genes. As well, AMPK inhibits mTOR complex (right) resulting in autophagy stimulation. Additionally, we show the established target of several compounds ( $\mathrm{Li}^{+}$, Metformin, Rapamicin, Resveratrol and Thiazolidinediones) on these intricate inter-linking signaling pathways to neuronal energy availability and cellular life span. Abbreviations: G, G-protein-coupled receptor; Dvl, Segment polarity protein disheveled homolog DVL-1; APC, adenomatous polyposis coli protein; Ca ${ }^{2+}$, calcium; $\mathrm{Ca}^{2+} / \mathrm{CaM}$-dependent protein kinase kinase $\beta$ (CaMKK $\beta$ ); AMPK, 5 ' adenosine monophosphate-activated protein kinase; mTOR, mechanistic target of rapamycin, Sirt1, silent mating-type information regulator 2 homolog 1; PGC-1a, peroxisome proliferator-activated receptor gamma

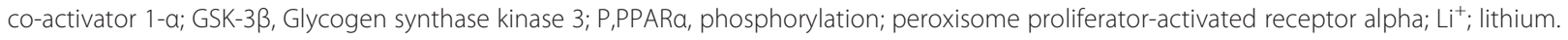

the biguanide class, can lead to activation of the AMPK and transcriptional up-regulation of $\beta$-secretase (BACE1), the rate-limiting enzyme for $A \beta$ generation, at therapeutic doses, and significantly increasing the generation of both intracellular and extracellular $A \beta$ species [64]. These findings suggest a potentially harmful effect for the use of metformin in diabetic elderly demented patients.

\section{Can new and old drugs that activate AMPK prevent AD?}

Several animal studies have highlighted the "anti-AD" effects of naturally occurring phytochemicals which have been shown to activate AMPK. For example, phytic acid [64], which is found in food grains could attenuate levels of ROS and $A \beta$ oligomers in transgenic mice, and moderately up-regulate the expression of the autophagy protein (beclin-1), Sirt1 and the AMPK pathway [65]. Moreover, arctigenin, derived from Arctium lappa, could reduce both $A \beta$ production by $\beta$-site amyloid precursor protein cleavage enzyme 1 , and enhance $A \beta$ clearance by potentiated autophagy by inhibition of protein kinase $B \mathrm{PKB} / \mathrm{mTOR}$ signaling, and AMPK activation, and improve memory in APP/PS1 AD mice [66]. Similarly, resveratrol promotes 
anti-ageing pathways and previously has been described as anti-AD agent [67]. Resveratrol has been previously shown to increase cytosolic $\mathrm{Ca}^{+2}$ levels and enhance AMPK activation through CAMKK2 activation, promoting autophagy degradation of $A \beta$ and reduced cerebral $A \beta$ deposition [59]. Another study showed that curcumin could up-regulate two new regulators of tau protein, BCL2-associated athanogene 2 (BAG2), and lysosomal-associated membrane protein 1 (LAMP1) [68]. As well, methylene blue has shown neuroprotective effects in neuropathological conditions [69] by promoting macroautophagy via AMPK activation rather than inhibition of mTOR pathway in vitro, and robustly increased the anti-apoptotic Bcl-2 protein levels [70]. A compound named butyrolactone, a product for $\gamma$-hydroxybutyric acid (GHB), also known as 4-hydroxybutanoic acid, a naturally occurring substance found in the CNS, as well as in wine, beef, and citrus fruits, increases the levels of the insulin-degrading enzyme (IDE), suppresses autophagy via the mTOR pathway, lowers $A \beta$ levels and prevents $A D$-like cognitive deficits in APP/PS1 mice [71].

Other authors have reported that topiramate (TPM) and levetiracetam (LEV), two classical drugs used in the management of epilepsy, alleviated behavioral deficits and diminished senile plaques in APP/PS1 mice. The mechanism underlying these observed effects involved increased $A \beta$ clearance and up-regulated $A \beta$ autophagic degradation through GSK-3 $\beta$ deactivation and AMPK activation [72]. Another recent study, showed that carbamazepine, an anticonvulsant and mood-stabilizing drug used primarily in the treatment of epilepsy and bipolar depression, demonstrates anti-AD effect in APP/ PS1 transgenic mice via mTOR-dependent pathway and increased autophagy, leading to reduced amyloid plaque load and $A \beta_{42}$ levels [73]. During a phase-II study, latrepirdine, an antihistaminic drug, also showed potent antiAD effects. In vitro, latrepirdine stimulated mTOR and ATG5 dependent autophagy, leading to the reduction of intracellular levels of APP metabolites, including A $\beta$ and the abrogation of behavioral deficit and autophagic malfunction in TgCRND8 mice [74]. Finally, rapamycin, which is extensively used in transplantation medicine to prevent organ rejection, represents a very attractive drug in $\mathrm{AD}$ because it can promote neuronal survival. However is has never been considered as a potential treatment for $\mathrm{AD}$ due to its potent immunosuppressive effect [75]. To date, the mechanism underlying the anti-AD properties of rapamycin are still debatable. However, it has been suggested that inhibition of mTOR by rapamycin improves cognitive deficits and rescues $A \beta$ pathology and NFTs through increased autophagy [76-78].

\section{The Sirt1-PGC-1a transcriptional complex}

Sirtuins are a new class of histone deacetylases dependent on the coenzyme nicotinamide adenine dinucleotide
$\left(\mathrm{NAD}^{+}\right)$as the essential substrate. Sirtuins are widely expressed through the mammalian body, but appear to be selectively localized at the subcellular level: Sirt3, 4 and 5 are primarily mitochondrial; Sirt1, 6 and 7 are mainly nuclear; while Sirt2 is the only sirtuin located in the cytosol [79]. Sirt3 regulates mitochondrial metabolism and may sense $\mathrm{NAD}^{+}$levels in the mitochondria, since increased $\mathrm{NAD}^{+}$triggers a regulatory pathway that would activate Sirt3 leading to the deacetylation of specific targets [80]. It has been demonstrated that mice deficient in Sirt3 present hyperacetylation [81] of the metabolic enzyme glutamate dehydrogenase (GDH), suggesting that Sirt3 may have profound impact on metabolic control [82].

Recent evidence suggests that mitochondrial biogenesis is regulated in part by PGC- $1 \alpha$, a transcriptional coactivator of PPAR $\gamma$, as well as other transcription factors [83]. It was therefore of considerable interest when it was shown that PGC-1 $\alpha$ activity was dependent on Sirt1-deacetylation [84]. Despite this, the role of PGC-1 $\alpha$ in $\mathrm{AD}$ remains unclear. Reduced PGC- $1 \alpha$ expression has been previously reported in brains of $\mathrm{AD}$ patients, and Tg2576 mice which have developed insulin resistance following chronic feeding with a high fat diet [85]. As well, PGC- $1 \alpha$ and its closely related isoform, PGC-1 $\beta$, are abundantly expressed and widely distributed in the brain, where they are thought to exhibit interchangeable roles for certain functions, such as maintenance of neuronal mitochondrial biogenesis [86].

Sirt1 has been shown to function together with PGC- $1 \alpha$ to promote adaptation to caloric restriction by regulating the genetic programs for gluconeogenesis and glycolysis in the liver. Sirt1 interacts with and deacetylates PGC1 $\alpha$ at multiple lysine sites, increasing PGC- $1 \alpha$ activity and leading to the induction of liver gluconeogenic genes transcription [87]. This interaction suggests that the Sirt1-PGC-1 $\alpha$ transcriptional complex may represent a core component of the brain neural circuitry concerned with modulating energy homeostasis.

\section{PGC-1a: a bioenergetics sensor in $A D$}

It has been suggested that mitochondrial biogenesis might be regulated by tissue energetic status, and that sirtuins may represent important energy sensors in this homeostatic loop. Indeed, the notion that PGC1 $\alpha$ acetylation and function, and by extension mitochondrial activity, are regulated in a nutrient-dependent fashion by Sirt1 is appealing. Nonetheless, the concept that Sirt1 in turn functions in response to nutrient-sensitive changes in basal $\mathrm{NAD}^{+}$levels, although often invoked, until recently has had little experimental support [88]. Resveratrol, a Sirt1 activator, induces mitochondrial biogenesis and protects against metabolic decline, but whether Sirt1 mediates these benefits is the subject of continuous debate. Interestingly, studies conducted in adult Sirt1 
conditional-knockout mice have shown that resveratrolmediated AMPK activation is dose-dependent, and that the Sirt1 is the key effector of this interaction. These data indicate that Sirt1 plays an essential role in stimulating $A M P K$, and improves mitochondrial function both in vitro and in vivo [89].

The Sirt1-PGC-1 $\alpha$ transcriptional complex has recently been implicated in the pathogenesis of $\mathrm{AD}$. One study showed that the transcription of BACE1 is modulated by up- or down regulation of PGC- $1 \alpha$ in vitro and in vivo, in eNOS-deficient mouse brains exposed to a high fat diet [90]. Modest fasting in these mice showed reduced BACE1 transcription in the brains, parallel to elevated PGC- $1 \alpha$ expression and activity. The inhibitory effect of PGC-1 $\alpha$ was dependent on activation of PPAR $\gamma$ via Sirt1-mediated deacetylation in a ligand-independent manner [90]. The direct interference between Sirt1-PPAR $\gamma$-PGC-1 $\alpha$ and BACE1 represents a unique non-canonical mechanism of Sirt1-PGC1 $\alpha$ in transcriptional repression in neurons in response to metabolic impairment.

\section{Exploring mitochondrial dysfunction in AD}

For almost two decades, the "amyloid cascade hypothesis" has dominated our understanding of the aetiology and progression of $\mathrm{AD}$. Briefly, this hypothesis suggested that accumulation of $A \beta$, a product of APP cleavage induces salient biochemical changes in the brain leading to the development of pathological and clinical changes observed in AD [91-93]. This hypothesis stems from the identification of an APP mutation in a family with autosomal dominant amyloid angiopathy, dementia, and AD-typical histology [94]. Two other genes that were subsequently found to contain mutations in autosomal dominant AD were PS1 and PS2 [95]. These protein form is important components of the $\gamma$-secretase complex, which is necessary for the processing of APP. While this hypothesis has been extrapolated to account for sporadic $A D$, it is important to note that sporadic AD patients do not have mutations in APP or PS genes, and the molecular basis for the accumulation of neurotoxic forms of $A \beta$ is unknown [96]. The "mitochondrial cascade hypothesis" was proposed in 2004 to provide a greater explanation for the continuous correlation between advancing age and $\mathrm{AD}$ risk, and to provide a more accurate explanation of the biochemical abnormalities that have been observed in $\mathrm{AD}$ patients $[97,98]$.

\section{Revisiting the mitochondrial cascade hypothesis of sporadic $A D$}

The "mitochondrial cascade hypothesis" emerged in response to the growing body of evidence for AD-related mitochondrial dysfunction $[97,98]$. Many studies have demonstrated that $A \beta$ can induce mitochondrial abnormalities. Since 1983, studies using transgenic animal models have demonstrated alterations in mitochondrial enzymes in the Alzheimer's disease brain. Moreover, FDG PET studies have shown that in AD, decreased glucose metabolism precedes clinical diagnosis. This could be interpreted as an early clinical finding of mitochondrial failure in $\operatorname{AD}[99,100]$.

The main evidence implicating mitochondrial dysfunction in $\mathrm{AD}$ can be summarized by at least five general statements: (i) reduced energy metabolism due to alterations in the key enzymes involved in oxidative phosphorylation, are associated with reduced neuronal expression of nuclear genes encoding subunits of the mitochondrial electron transport chain [101], (ii) $\mathrm{Ca}^{2+}$ imbalance through impaired buffering capacity and modifications to the endoplasmic reticulum (ER) $\mathrm{Ca}^{2+}$ channels leads to neuronal apoptosis, triggered by the calmodulin-dependent kinase and calpain activations [102,103]; (iii) abnormal mitochondrial dynamics have revealed significantly reduced mitochondrial length. In biopsied AD brains, biochemical data collectively suggest that there is likely enhanced fission, overexpression of dynamin-like protein 1 protein (DLP1) and down regulation of the optic atrophy protein 1 (OPA1) [104]; (iv) mitochondrial biogenesis is regulated by the Sirt1-PGC-1 $\alpha$ axis and nuclear respiratory factor (NRF). In hippocampal tissues from AD patients and APP mice M17 cells, the levels of PGC- $1 \alpha$, NRF1and NRF2 were significantly decreased in comparison with healthy patients and wild type mice [105]. In this sense, PGC-1 $\alpha$ overexpression has been shown to be neuroprotective both in in vitro and in vivo in several models for neurodegenerative diseases. Contrary to these findings, a recent study showed that continuous PGC-1 $\alpha$ overexpression was cytotoxic to dopaminergic neurons in vivo [106,107]; (v) finally, by products of macromolecular oxidation, such as 4-hydroxynonenal (4-HNE), which is produced by lipid peroxidation in cells, may facilitate the self-assembly of tau protein into fibrillar polymers similar to those found in paired helical filaments (PHF), present in the brain of AD patients. These result strong suggest that oxidative stress, either by itself or as part of a "two hit process", causes neuronal dysfunction, and AD [108].

\section{Overcoming mitochondrial damage as an anti-ageing approach}

Tremendous investments in basic research have been focused on preserving mitochondrial function in $\mathrm{AD}$. Multiple approaches include strategies aimed at increasing mitochondrial mass, promoting fusion-fission balance, preventing mitochondrial $\mathrm{Ca}^{+2}$ overload, avoiding membrane swelling and improving the overall redox status. Novel therapeutics which exert a positive effect on these targets, may reinforce energy delivery from the mitochondria [109]. In this regard, dietary zeolite (micronized zeolite) 
supplementation has been shown to reduce mitochondrial ROS, increase superoxide dismutase (SOD) levels, and attenuate $\mathrm{A} \beta$ accumulation in the APP/PS1 mouse brain [110]. In the same way, Salvia sahendica extracts prevented reduction in the level of NRF1 and mitochondrial transcription factor $A$ (TFAM), induced by $A \beta$ [111]. In another study, melatonin and caffeine treatment, almost completely restored mitochondrial function in assays of respiratory rate, membrane potential, ROS production, and ATP level in the brains of the APP/PS1 [112]. Apigenin, a poor toxic and non-mutagenic subclass of flavonoid, has been reported to reduce the toxic effects of $A \beta$, although it did not provide a sufficient effect on decreasing APP expression and A $\beta$ burden; However, restitution of redox balance due to increased intracellular glutathione levels and potentiation of cellular SOD and glutathione peroxidase activities was noted [72]. Treatment of 3xTgAD mice with nicotinamide also resulted in improved cognitive performance, concordant with normalizing mitochondrial dynamics and increased expression of the fission protein, DLP1 in the cerebral cortex [68]. We have previously demonstrated that St. John's wort semisynthetic derivate $\mathrm{THH}$ counteracts oxidative insult in APP/PS1 mice brain, by reducing the formation of 4-HNE adducts and caspase-3 activation [36]. The underlying mechanism of action seems to be related to the prevention of mitochondrial $\mathrm{Ca}^{2+}$ overload, and modulation of the fusion-fission process, arresting mitochondrial dysfunction [36]. In the other hand, moderate exercise promotes increased activity of the mitochondrial complexes I, III and IV in the brain and prevents age-dependent mitochondrial decline reported in sedentary rodents [113].

As well, another study demonstrated that brain adaptations to endurance training included overexpression of PGC- $1 \alpha$ and Sirt1 mRNA overexpression, together with increased mitochondrial DNA content, suggesting increased mitochondrial mass [114]. Similarly, it is also well known that exercise induces the regulation of brain mitochondrial redox balance, and chronic exercise reduces apoptotic signaling in the AD brain [115]. Finally, different approaches using 10 selected polyphenols, shown to ameliorate membrane disruption caused by the $A \beta_{42}$ peptide, and tau- 441 proteins, suggest that these abnormal protein aggregates might interfering with the mitochondrial membrane [116].

The maintenance of intracellular $\mathrm{NAD}^{+}$levels in human brain cells may also be crucial for the retention of cellular viability during conditions of chronic oxidative stress and mitochondrial dysfunction through the promotion of oxidative phosphorylation (ATP production). $\mathrm{NAD}^{+}$is also closely associated with the DNA binding family of enzymes known as poly (ADP-ribose) polymerases (PARPs) $[117,118]$. Under physiological conditions, PARP activation leads to DNA repair and recovery of normal cellular function. However, under pathological conditions, PARP activation leads to increased $\mathrm{NAD}^{+}$turnover, leads to reduced ATP synthesis, and the cessation of all energy dependent functions and consequent cell death [119-121]. Increased levels of functional PARP enzyme have been reported in the frontal and temporal cortex more frequently than age-matched controls in postmortem brains of $\mathrm{AD}$ patients. Maintenance of intracellular $\mathrm{NAD}^{+}$pools may reduce cellular injury. $\mathrm{NAD}^{+}$treatment has been shown to reduce PARP-induced astrocyte death [122]. Additionally, $\mathrm{NAD}^{+}$may also prevent neuronal injury by enhancing sirtuin activities and/or improving energy metabolism [123].

\section{Conclusion}

As the world's ageing population continues to increase and age appears to be a prominent risk factor for most neurodegenerative diseases, novel therapeutic regimens which delay the onset of age-related disorders are highly desirable. There are multiple connections between neurodegenerative diseases, such as increased oxidative stress, decreased autophagy, and formation of misfolded proteins, impaired neuronal metabolism and mitochondrial dysfunction. Central to the maintenance of cellular function, and particularly synaptic structure and function, and mitochondrial integrity are the proto-oncogene Wnt, AMPK, mTOR, Sirt1 and PGC-1 $\alpha$. Wht signaling activation (Figure 2), which protects neurons against neurotoxic damage and, in this sense, represents a new perspective regarding the underlying pathobiology of AD. Furthermore, strong evidence suggests that AMPK might be key master controller of important metabolic pathways and is closely aligned with Sirt1 and mTOR activities. Moreover, the crosstalk between these main pathways, as well as, with secondary cellular mechanisms are far to be addressed, but the currently available evidence suggest a more than plausible connection between the pathways herein presented. Of course important questions should be answered in order to fulfill the inconsistencies of some observations. Mainly, that several research groups have conducted some clinical trials using different kinds of drugs, such as PPAR $\gamma$ agonists (TZD) or SIRT1 agonists (Res), with disappointing results [124]; however, according to our experience, these sort of negative results are not due to the lack of action of the drug, but probably because of the inner complexity of the disease, and the lack of understanding between live animal models and human physiological response [125-131]. Moreover, researchers still avoid considering the response of adjacent tissues as a result of systemic AD therapies; what if the systemic administration of some drug induces an alteration of the blood-brain barrier health, limiting the further benefits of the drug within the brain parenchyma? Today, AD research is usually focused to unveil limited areas of the disease with unsuccessful results 
when challenged in real patients, we believe that through renewed insight on the cellular and molecular mechanisms responsible for cellular and mitochondrial abnormalities reported in AD, efficient and safe translation of these signaling pathways into novel therapeutic alternatives against neuronal degeneration may shorten the gap between basic science and clinical research. The fast and efficient translation of innovative therapeutics into clinical candidates, and eventually approved therapeutics will improve outcomes for AD patients.

\begin{abstract}
Abbreviations
AMPK: 5 ' adenosine monophosphate-activated protein kinase; mTOR: Mammalian target of rapamycin; Sirt1: Silent mating-type information regulator 2 homolog 1; PGC1: Peroxisome proliferator-activated receptor gamma coactivator 1-alpha; AD: Alzheimer's disease; AB: Amyloid beta; NFT: Neurofibrillary tangles; Fz: Frizzled; APP: Amyloid precursor protein; DSH: Disheveled; PKC: Protein kinase C; LRP6: Low density lipoprotein-related receptor protein; apoE4: Allele 4 of apo-lipoprotein E; PPAR: Peroxisome proliferator-activated receptor; $A \beta O$ : $A \beta$ oligomers;

AChE: Acetylcholinesterase; THH: Tetrahydrohyperforin; AChR: Acetylcholine receptors; C. elegans: Caenorhabditis elegans; STK11: Serine/threonine kinase 11; CaMKK: $\mathrm{Ca}^{2+} / \mathrm{CaM}-d e p e n d e n t$ protein kinase kinase $\beta$; PPase: Phosphatases; FOXO3: Forkhead box O3; LTP: Long-term potentiation; BACE1: $\beta$-secretase; BAG2: BCL2-associated athanogene 2; LAMP1: Lysosomal-associated membrane protein 1; GHB: $\gamma$-Hydroxybutyric acid; IDE: Insulin-degrading enzyme; TPM: Topiramate; LEV: Levetiracetam; NAD+: Nicotinamide adenine dinucleotide; GDH: Glutamate dehydrogenase; DLP1: Dynamin-like protein 1 protein; OPA1: Optic atrophy protein 1; NRF: Nuclear respiratory factor; 4-HNE: 4-hydroxynonenal; PHF: Paired helical filaments; TFAM: Mitochondrial transcription factor A; PARPs: Poly(ADP-ribose) polymerases; NO: Nitric oxide; SOD: Superoxide dismutase.
\end{abstract}

\section{Competing interests}

The authors declare no conflict of interest related to this study.

\section{Authors' contributions}

JAG, JAR, JMZ, NB and NI drafted and wrote the manuscript. All authors read and approved the final manuscript.

\section{Acknowledgments}

This work was supported by grants PFB 12/2007 from the Basal Centre for Excellence in Science and Technology, FONDECYT 1120156, MIFAB Foundation, Fundacion Ciencia y Vida to NCl; a Pre-doctoral Fellowship from CONYCIT fellowship to JAR; and FONDECYT 11130033 to JMZ. NB is a recipient of the Alzheimer's Australia and NHMRC Early Career Postdoctoral Research Fellowship at the University of New South Wales, Sydney, Australia.

\section{Author details}

Centro de Envejecimiento y Regeneración (CARE); Departamento de Biología Celular y Molecular; Facultad de Ciencias Biológicas, Pontificia Universidad Católica de Chile, Av. Alameda 340, Santiago, Chile. ²Departamento de Biología, Facultad de Ciencias, Universidad de Tarapacá, Arica, Chile. ${ }^{3}$ Center for Healthy Brain Ageing, School of Psychiatry, Faculty of Medicine, University of New South Wales, Sydney, Australia.

Received: 30 January 2014 Accepted: 11 March 2014

Published: 28 March 2014

\section{References}

1. Selkoe DJ, Mandelkow E, Holtzman D: Deciphering Alzheimer disease. Cold Spring Harbor Perspect Med 2012, 2:a011460.

2. Hirai K, Aliev G, Nunomura A, Fujioka H, Russell RL, Atwood CS, Johnson AB, Kress Y, Vinters HV, Tabaton M, Shimohama S, Cash AD, Siedlak SL, Harris PL, Jones PK, Petersen RB, Perry G, Smith MA: Mitochondrial abnormalities in Alzheimer's disease. (J Neurosci 2001, 21:3017-3023.

3. Mattson M: Pathways towards and away from Alzheimer's disease. Nature 2004, 430:631-639.
4. Nusse R, Varmus $\mathrm{H}$ : Three decades of Wnts; a personal perspective on how a scientific field developed. EMBO J 2012, 31:2670-2682.

5. Clevers H, Nusse R: Wnt/ $\beta$-catenin signaling and disease. Cell 2012, 149:1192-1205.

6. Angers S, Moon RT: Proximal events in Wnt signal transduction. Nat Rev Mol Cell Biol 2009, 10:468-477.

7. Ciani L, Salinas P: WNTs in the vertebrate nervous system nervous system: from patterning to neuronal connectivity. Nat Rev Neurosci 2005, 6:351-362.

8. Rosso SB, Inestrosa NC: WNT signaling in neuronal maturation and synaptogenesis. Frontiers Cell Neurosci 2013, 7:103.

9. Zhang Z, Hartmann H, Do VM, Abramowski D, Sturchler-Pierrat C, Staufenbiel M, Sommer B, van de Wetering M, Clevers H, Saftig P, De Strooper B, He X, Yankner BA: Destabilization of beta-catenin by mutations in presenilin-1 potentiates neuronal apoptosis. Nature 1998, 395:698-702.

10. De Ferrari GV, Chacon MA, Barria MI, Garrido JL, Godoy JA, Olivares G, Reyes $A E$, Alvarez A, Bronfman M, Inestrosa NC: Activation of Wnt signaling rescues neurodegeneration and behavioral impairments induced by beta-amyloid fibrils. Mol Psychiat 2003, 8:195-208.

11. Alvarez A, Godoy JA, Mullendorff K, Olivares GH, Bronfman M, Inestrosa NC Wnt-3a overcomes beta-amyloid toxicity in rat hippocampal neurons. Exp Cell Res 2004, 297:186-196.

12. Caricasole A, Copani A, Caruso A, Caraci F, lacovelli L, Sortino MA, Terstappen GC, Nicoletti F: The Wnt pathway, cell-cycle activation and beta-amyloid: novel therapeutic strategies in Alzheimer's disease? Trends Pharmacol Sci 2003, 24:233-238.

13. Caricasole A, Copani A, Caraci F, Aronica E, Rozemuller AJ, Caruso A, Storto M, Gaviraghi G, Terstappen GC, Nicoletti F: Induction of Dickkopf-1, a negative modulator of the Wnt pathway, is associated with neuronal degeneration in Alzheimer's brain. J Neurosci 2004, 24:6021-6027.

14. Rosi MC, Luccarini I, Grossi C, Fiorentini A, Spillantini MG, Prisco A, Scali C, Gianfriddo M, Caricasole A, Terstappen GC, Casamenti F: Increased Dickkopf-1 expression in transgenic mouse models of neurodegenerative disease. J Neurochem. 2010, 112:1539-1551.

15. Zenzmaier C, Marksteiner J, Kiefer A, Berger P, Humpel C: Dkk-3 is elevated in CSF and plasma of Alzheimer's disease patients. J Neurochem 2009, 110:653-661.

16. Caruso A, Motolese M, lacovelli L, Caraci F, Copani A, Nicoletti F, Terstappen GC, Gaviraghi G, Caricasole A: Inhibition of the canonical Wnt signaling pathway by apolipoprotein E4 in PC12 cells. J Neurochem 2006, 98:364-371.

17. De Ferrari GV, Papassotiropoulos A, Biechele T, Wavrant De-Vrieze F, Avila ME, Major MB, Myers A, Saez K, Henriquez JP, Zhao A, Wollmer MA, Nitsch RM, Hock C, Morris CM, Hardy J, Moon RT: Common genetic variation within the low-density lipoprotein receptor-related protein 6 and late-onset Alzheimer's disease. Proceedings of the National Academy of Sciences of the United States of America 2007, 104:9434-9439.

18. Purro SA, Dickins EM, Salinas PC: The secreted Wnt antagonist Dickkopf-1 is required for amyloid-beta-mediated synaptic loss. J Neurosci 2012 32:3492-3498

19. Purro SA, Galli S, Salinas PC: Dysfunction of Wnt signaling and synaptic disassembly in neurodegenerative diseases. J Mol Cell Biol 2014, 6:75-80

20. Killick R, Ribe E, Ribe EM, Al-Shawi R, Malik B, Hooper C, Fernandes C, Dobson R, Nolan PM, Lourdusamy A, Furney S, Lin K, Breen G, Wroe R, To AW, Leroy K, Causevic M, Usardi A, Robinson M, Noble W, Williamson R, Lunnon K, Kellie S, Reynolds CH, Bazenet C, Hodges A, Brion JP, Stephenson J, Simons JP, Lovestone S: Clusterin regulates $\beta$-amyloid toxicity via Dickkopf-1-driven induction of the Wnt-PCP-JNK pathway. Molecular psychiatry 2014, 19:88-98. 19:88-98.

21. Serrano-Pozo A, Frosch MP, Masliah E, Hyman BT: Neuropathological alterations in Alzheimer disease. Cold Spring Harbor Perspect Med 2011 1:a006189

22. Cerpa W, Farias GG, Godoy JA, Fuenzalida M, Bonansco C, Inestrosa NC: Wnt-5a occludes Abeta oligomer-induced depression of glutamatergic transmission in hippocampal neurons. Mol Neurodegeneration 2010, 5:3.

23. Muñoz FJ, Godoy JA, Cerpa W, Poblete IM, Huidobro-Toro JP, Inestrosa NC: Wnt-5a increases NO and modulates NMDA receptor in rat hippocampal neurons. Biochem Biophys Res Commun 2014, 444:189-194.

24. Coutiño L, Godoy JA, Couve A, Fuenzalida M, Inestrosa NC: Wnt-5a modulates recycling of functional GABAA receptors on hippocampal neurons. J Neurosci 2010, 30:8411-8420. 
25. Farias GG, Alfaro IE, Cerpa W, Grabowski CP, Godoy JA, Bonansco C, Inestrosa NC: Wnt-5a/JNK signaling promotes the clustering of PSD-95 in hippocampal neurons. J Biol Chem 2009, 284:15857-15866.

26. Varela-Nallar L, Alfaro IE, Serrano FG, Parodi J, Inestrosa NC: Wingless-type family member $5 \mathrm{~A}$ (Wnt-5a) stimulates synaptic differentiation and function of glutamatergic synapses. Proc Natl Acad Sci U S A 2010, 107:21164-21169.

27. Silva-Alvarez C, Arrazola MS, Godoy JA, Ordenes D, Inestrosa NC: Canonical Wnt signaling protects hippocampal neurons from Abeta oligomers: role of non-canonical Wnt-5a/Ca(2+) in mitochondrial dynamics. Frontiers Cell Neurosci 2013, 7:97.

28. Vargas J, Fuenzalida M, Inestrosa NC: In vivo activation of Wnt signaling pathway enhances cognitive function of adult mice and reverses cognitive deficits in an Alzheimer's disease model. J Neurosci 2014, 34:2191-2202.

29. Inestrosa NC, Varela-Nallar L: Wnt signaling in the nervous system and in Alzheimer's disease. J Mol Cell Biol 2014, 6:64-74.

30. Inestrosa NC, Toledo EM: The role of Wnt signaling in neuronal dysfunction in Alzheimer's disease. Mol Neurodegeneration 2008, 3:9.

31. Inestrosa NC, Arenas E: Emerging roles of Wnts in the adult nervous system. Nat Rev Neurosci 2010, 11:77-86.

32. Dumas JA, Newhouse PA: The cholinergic hypothesis of cognitive aging revisited again: cholinergic functional compensation. Pharmacol Biochem Behav 2011, 99:254-261.

33. Inestrosa NC, Alvarez A, Perez CA, Moreno RD, Vicente M, Linker C, Casanueva Ol, Soto C, Garrido J: Acetylcholinesterase accelerates assembly of amyloid-beta-peptides into Alzheimer's fibrils: possible role of the peripheral site of the enzyme. Neuron 1996, 16:881-891.

34. Munoz FJ, Inestrosa NC: Neurotoxicity of acetylcholinesterase amyloid beta-peptide aggregates is dependent on the type of Abeta peptide and the AChE concentration present in the complexes. FEBS letters 1999, 450:205-209.

35. Cerpa W, Hancke JL, Morazzoni P, Bombardelli E, Riva A, Marin PP, Inestrosa NC: The hyperforin derivative IDN5706 occludes spatial memory impairments and neuropathological changes in a double transgenic Alzheimer's mouse model. Curr Alzheimer Res 2010, 7:126-133.

36. Dinamarca MC, Arrazola M, Toledo E, Cerpa WF, Hancke J, Inestrosa NC: Release of acetylcholinesterase (AChE) from beta-amyloid plaques assemblies improves the spatial memory impairments in APP-transgenic mice. Chem Biol Interact 2008, 175:142-149.

37. Carvajal FJ, Zolezzi JM, Tapia-Rojas C, Godoy JA, Inestrosa NC: Tetrahydrohyperforin decreases cholinergic markers associated with amyloid-beta plaques, 4-hydroxynonenal formation, and caspase-3 activation in AbetaPP/PS1 mice. J Alzheimers Dis 2013, 36:99-118.

38. Jensen M, Hoerndli FJ, Brockie PJ, Wang R, Johnson E, Maxfield D, Francis MM, Madsen DM, Maricq AV: Wnt signaling regulates acetylcholine receptor translocation and synaptic plasticity in the adult nervous system. Cell 2012, 149:173-187.

39. Jensen M, Brockie PJ, Maricq AV: Wnt signaling regulates experiencedependent synaptic plasticity in the adult nervous system. Cell Cycle 2012, 11:2585-2586.

40. Lee HP, Zhu X, Casadesus G, Castellani RJ, Nunomura A, Smith MA, Lee HG, Perry G: Antioxidant approaches for the treatment of Alzheimer's disease. Expert Rev Neurother 2010, 10:1201-1208.

41. Habib LK, Lee MT, Yang J: Inhibitors of catalase-amyloid interactions protect cells from beta-amyloid-induced oxidative stress and toxicity. J Biol Chem 2010, 285:38933-38943.

42. Quintanilla RA, Munoz FJ, Metcalfe MJ, Hitschfeld M, Olivares G, Godoy JA, Inestrosa NC: Trolox and 17beta-estradiol protect against amyloid beta-peptide neurotoxicity by a mechanism that involves modulation of the Wnt signaling pathway. J Biol Chem 2005, 280:11615-11625.

43. Inestrosa NC, Carvajal FJ, Zolezzi JM, Tapia-Rojas C, Serrano F, Karmelic D, Toledo EM, Toro A, Toro J, Santos MJ: Peroxisome proliferators reduce spatial memory impairment, synaptic failure, and neurodegeneration in brains of a double transgenic mice model of Alzheimer's disease. J Alzheimers Dis 2013, 33:941-959.

44. Miyaoka T, Seno H, Ishino H: Increased expression of Wnt-1 in schizophrenic brains. Schizophr Res 1999, 38:1-6.

45. Wagner U, Brownlees J, Irving NG, Lucas FR, Salinas PC, Miller CC: Overexpression of the mouse dishevelled-1 protein inhibits GSK-3betamediated phosphorylation of tau in transfected mammalian cells. Febs Lett 1997, 411:369-372
46. Carling D, Thornton C, Woods A, Sanders MJ: AMP-activated protein kinase: new regulation, new roles? Biochem J 2012, 445:11-27.

47. Zhang J, Xie Z, Dong Y, Wang S, Liu C, Zou MH: Identification of nitric oxide as an endogenous activator of the AMP-activated protein kinase in vascular endothelial cells. J Biol Chem 2008, 283:27452-27461.

48. Ruderman NB, Carling D, Prentki M, Cacicedo JM: AMPK, insulin resistance, and the metabolic syndrome. J Clin Invest 2013, 123:2764-2772.

49. Hardie DG, Ross FA, Hawley SA: AMP-activated protein kinase: a target for drugs both ancient and modern. Chem Biol 2012, 19:1222-1236.

50. Jager S, Handschin C, St-Pierre J, Spiegelman BM: AMP-activated protein kinase (AMPK) action in skeletal muscle via direct phosphorylation of PGC-1a. Proc Natl Acad Sci U S A 2007, 104:12017-12022.

51. Greer EL, Oskoui PR, Banko MR, Maniar JM, Gygi MP, Gygi SP, Brunet A: The energy sensor AMP-activated protein kinase directly regulates the mammalian FOXO3 transcription factor. J Biol Chem 2007, 282:30107-30119.

52. Egan DF, Shackelford DB, Mihaylova MM, Gelino S, Kohnz RA, Mair W, Vasquez DS, Joshi A, Gwinn DM, Taylor R, Asara JM, Fitzpatrick J, Dillin A, Viollet B, Kundu M, Hansen M, Shaw RJ: Phosphorylation of ULK1 (hATG1) by AMP-activated protein kinase connects energy sensing to mitophagy. Science 2011, 331:456-461.

53. Alers S, Loffler AS, Wesselborg S, Stork B: Role of AMPK-mTOR-Ulk1/2 in the regulation of autophagy: cross talk, shortcuts, and feedbacks. $\mathrm{Mol}$ Cell Biol 2012, 32:2-11.

54. Garelick MG, Kennedy BK: TOR on the brain. Exp Gerontol 2011, 46:155-163.

55. Caberlotto L, Lauria M, Nguyen TP, Scotti M: The central role of AMP-kinase and energy homeostasis impairment in Alzheimer's disease: a multifactor network analysis. PloS One 2013, 8:e78919.

56. Yates SC, Zafar A, Hubbard P, Nagy S, Durant S, Bicknell R, Wilcock G, Christie S, Esiri MM, Smith AD, Nagy Z: Dysfunction of the mTOR pathway is a risk factor for Alzheimer's disease. Acta Neuropathologica Commun 2013, 1:3.

57. Greco SJ, Sarkar S, Johnston JM, Tezapsidis N: Leptin regulates tau phosphorylation and amyloid through AMPK in neuronal cells. Biochem Biophys Res Commun 2009, 380:98-104.

58. Thornton C, Bright NJ, Sastre M, Muckett PJ, Carling D: AMP-activated protein kinase (AMPK) is a tau kinase, activated in response to amyloid beta-peptide exposure. Biochem Med 2011, 434:503-512.

59. Vingtdeux $V$, Davies $P$, Dickson DW, Marambaud P: AMPK is abnormally activated in tangle- and pre-tangle-bearing neurons in Alzheimer's disease and other tauopathies. Acta Neuropathol 2011, 121:337-349.

60. Vingtdeux V, Giliberto L, Zhao H, Chandakkar P, Wu Q, Simon JE, Janle EM, Lobo J, Ferruzzi MG, Davies P, Marambaud P: AMP-activated protein kinase signaling activation by resveratrol modulates amyloid-beta peptide metabolism. J Biol Chem 2010, 285:9100-9113.

61. Cai Z, Yan LJ, Li K, Quazi SH, Zhao B: Roles of AMP-activated protein kinase in Alzheimer's disease. Neuromolecular Med 2012, 14:1-14.

62. Cai Z, Li B, Li K, Zhao B: Down-regulation of amyloid-beta through AMPK activation by inhibitors of GSK-3beta in SH-SY5Y and SH-SY5Y-AbetaPP695 cells. J Alzheimers Dis 2012, 29:89-98.

63. Ghavami S, Shojaei S, Yeganeh B, Ande SR, Jangamreddy JR, Mehrpour M, Christoffersson J, Chaabane W, Moghadam AR, Kashani HH, Hashemi M, Owji AA, Los MJ: Autophagy and apoptosis dysfunction in neurodegenerative disorders. Progr Neurobio/ 2014, 112:24-49.

64. Tan CC, Yu JT, Tan MS, Jiang T, Zhu XC, Tan L: Autophagy in aging and neurodegenerative diseases: implications for pathogenesis and therapy. Neurobiol Aging 2013, 35:941-957

65. Chen Y, Zhou K, Wang R, Liu Y, Kwak YD, Ma T, Thompson RC, Zhao Y, Smith L, Gasparini L, Luo Z, Xu H, Liao FF: Antidiabetic drug metformin (GlucophageR) increases biogenesis of Alzheimer's amyloid peptides via up-regulating BACE1 transcription. Proceedings of the National Academy of Sciences of the United States of America 2009, 106:3907-3912.

66. Anekonda TS, Wadsworth TL, Sabin R, Frahler K, Harris C, Petriko B, Ralle M, Woltjer R, Quinn JF: Phytic acid as a potential treatment for alzheimer's pathology: evidence from animal and in vitro models. J Alzheimers Dis 2011, 23:21-35.

67. Zhu Z, Yan J, Jiang W, Yao XG, Chen J, Chen L, Li C, Hu L, Jiang H, Shen X: Arctigenin effectively ameliorates memory impairment in Alzheimer's disease model mice targeting both beta-amyloid production and clearance. J Neurosci 2013, 33:13138-13149.

68. Zhao L, Wang JL, Wang YR, Fa XZ: Apigenin attenuates copper-mediated beta-amyloid neurotoxicity through antioxidation, mitochondrion 
protection and MAPK signal inactivation in an AD cell model. Brain Res 2013, 1492:33-45.

69. Patil SP, Tran N, Geekiyanage H, Liu L, Chan C: Curcumin-induced upregulation of the anti-tau cochaperone BAG2 in primary rat cortical neurons. Neurosci Lett 2013, 554:121-125.

70. Congdon EE, Wu JW, Myeku N, Figueroa YH, Herman M, Marinec PS Gestwicki JE, Dickey CA, Yu WH, Duff KE: Methylthioninium chloride (methylene blue) induces autophagy and attenuates tauopathy in vitro and in vivo. Autophagy 2012, 8:609-622.

71. Xie L, Li W, Winters A, Yuan F, Jin K, Yang S: Methylene blue induces macroautophagy through 5 ' adenosine monophosphate-activated protein kinase pathway to protect neurons from serum deprivation. Front Cell Neurosci 2013, 7:56.

72. Wei L, Yang H, Xie Z, Yang S, Yang H, Zhao C, Wang P, Xu S, Miao J, Zhao B, $\mathrm{Bi}$ J: A butyrolactone derivative 3BDO alleviates memory deficits and reduces amyloid-beta deposition in an AbetaPP/PS1 transgenic mouse model. J Alzheimers Dis 2012, 30:531-543.

73. Shi JQ, Wang BR, Tian YY, Xu J, Gao L, Zhao SL, Jiang T, Xie HG, Zhang YD: Antiepileptics Topiramate and Levetiracetam Alleviate Behavioral Deficits and Reduce Neuropathology in APPswe/PS1dE9 Transgenic Mice. CNS Neurosci Ther 2013, 19:871-881.

74. Li L, Zhang S, Zhang X, Li T, Tang Y, Liu H, Yang W, Le W: Autophagy enhancer carbamazepine alleviates memory deficits and cerebral amyloid-beta pathology in a mouse model of Alzheimer's disease. Curr Alzheimer Res 2013, 10:433-441.

75. Steele JW, Gandy S: Latrepirdine (Dimebon(R)), a potential Alzheimer therapeutic, regulates autophagy and neuropathology in an Alzheimer mouse model. Autophagy 2013, 9:617-618.

76. Santos RX, Correia SC, Cardoso S, Carvalho C, Santos MS, Moreira PI: Effects of rapamycin and TOR on aging and memory: implications for Alzheimer's disease. J Neurochem 2011, 117:927-936.

77. Cai Z, Zhao B, Li K, Zhang L, Li C, Quazi SH, Tan Y: Mammalian target of rapamycin: a valid therapeutic target through the autophagy pathway for Alzheimer's disease? J Neurosci Res 2012, 90:1105-1118.

78. Caccamo A, Majumder S, Richardson A, Strong R, Oddo S: Molecular interplay between mammalian target of rapamycin (mTOR), amyloid-beta, and Tau: effects on cognitive impairments. J Biol Chem 2010, 285:13107-13120.

79. Majumder S, Richardson A, Strong R, Oddo S: Inducing autophagy by rapamycin before, but not after, the formation of plaques and tangles ameliorates cognitive deficits. PLoS One 2011, 6:e25416.

80. Godoy JA, Zolezzi JM, Braidy N, Inestrosa NC: Role of Sirt1 during the ageing process: relevance to protection of synapses in the brain. Mol Neurobiol 2013. doi:10.1007/s12035-014-8645-5.

81. Rose G, Dato S, Altomare K, Bellizzi D, Garasto S, Greco V, Passarino G, Feraco E, Mari V, Barbi C, BonaFe M, Franceschi C, Tan Q, Boikos S, Yashin Al, De Benedictis G: Variability of the SIRT3 gene, human silent information regulator Sir2 homologue, and survivorship in the elderly. Exp Gerontol 2003, 38:1065-1070.

82. Lombard DB, Alt FW, Cheng HL, Bunkenborg J, Streeper RS, Mostoslavsky R, Kim J, Yancopoulos G, Valenzuela D, Murphy A, Yang Y, Chen Y, Hirschey MD, Bronson RT, Haigis M, Guarente LP, Farese RV Jr, Weissman S, Verdin E, Schwer B: Mammalian Sir2 homolog SIRT3 regulates global mitochondrial lysine acetylation. Mol Cell Biol 2007, 27:8807-8814.

83. Schlicker C, Gertz M, Papatheodorou P, Kachholz B, Becker CF, Steegborn C Substrates and regulation mechanisms for the human mitochondrial sirtuins Sirt3 and Sirt5. J Mol Biol 2008, 382:790-801.

84. Fernandez-Marcos PJ, Auwerx J: Regulation of PGC-1a, a nodal regulator of mitochondrial biogenesis. Am J Clin Nutr 2011, 93:884S-890

85. Nemoto S, Fergusson MM, Finkel T: SIRT1 functionally interacts with the metabolic regulator and transcriptional coactivator PGC-1a.J Biol Chem 2005, 280:16456-16460.

86. Katsouri L, Parr C, Bogdanovic N, Willem M, Sastre M: PPARgamma coactivator-1alpha (PGC-1alpha) reduces amyloid-beta generation through a PPARgamma-dependent mechanism. J Alzheimers Dis 2011, 25:151-162.

87. Wareski P, Vaarmann A, Choubey V, Safiulina D, Liiv J, Kuum M, Kaasik A: PGC-1 $\alpha$ and PGC-1 $\beta$ regulate mitochondrial density in neurons. J Biol Chem 2009, 284:21379-21385.

88. Yamamoto T, Shimano H, Nakagawa Y, Ide T, Yahagi N, Matsuzaka T, Nakakuki M, Takahashi A, Suzuki H, Sone H, Toyoshima H, Sato R, Yamada N: SREBP-1 interacts with hepatocyte nuclear factor- 4 alpha and interferes with PGC-1 recruitment to suppress hepatic gluconeogenic genes. J Biol Chem 2004, 279:12027-12035.

89. Sack MN, Finkel T: Mitochondrial metabolism, sirtuins, and aging. Cold Spring Harb Perspect Biol 2012, 4. doi:10.1101/cshperspect.a013102.

90. Price NL, Gomes AP, Ling AJ, Duarte FV, Martin-Montalvo A, North BJ, Agarwal B, Ye L, Ramadori G, Teodoro JS, Hubbard BP, Varela AT, Davis JG, Varamini B, Hafner A, Moaddel R, Rolo AP, Coppari R, Palmeira CM, de Cabo $\mathrm{R}$, Baur JA, Sinclair DA: SIRT1 is required for AMPK activation and the beneficial effects of resveratrol on mitochondrial function. Cell Metabol 2012, 15:675-690.

91. Wang R, Li JJ, Diao S, Kwak YD, Liu L, Zhi L, Bueler H, Bhat NR, Williams RW Park EA, Liao FF: Metabolic stress modulates Alzheimer's beta-secretase gene transcription via SIRT1-PPARgamma-PGC-1 in neurons. Cell Metab 2013, 17:685-694.

92. Hardy J: Alzheimer's disease: the amyloid cascade hypothesis: an update and reappraisal. J Alzheimers Dis 2006, 9:151-153.

93. Hardy J: Has the amyloid cascade hypothesis for Alzheimer's disease been proved? Curr Alzheimer Res 2006, 3:71-73.

94. Hardy JA, Higgins GA: Alzheimer's disease: the amyloid cascade hypothesis. Science 1992, 256:184-185.

95. Goate A, Chartier-Harlin MC, Mullan M, Brown J, Crawford F, Fidani L, Giuffra L, Haynes A, Irving N, James L, Mant R, Newton P, Rooke K, Roques P, Talbot C, Pericak-Vance M, Roses A, Williamson R, Rossor M, Owen M, Hardy J: Segregation of a missense mutation in the amyloid precursor protein gene with familial Alzheimer's disease. Nature 1991, 349:704-706.

96. Sherrington R, Rogaev El, Liang Y, Rogaeva EA, Levesque G, Ikeda M, Chi $H_{\text {, }}$ Lin C, Li G, Holman K, Tsuda T, Mar L, Foncin JF, Bruni AC, Montesi MP, Sorbi P, Rainero I, Pinessi L, Nee L, Chumakov I, Pollen D, Brookes A, Sanseau P, Polinsky RJ, Wasco W, Da Silva HA, Haines J, Perkicak-Vance MA, Tanzi RE, Roses AD, Fraser PE, Rommens JM, St George-Hyslop PH: Cloning of a gene bearing missense mutations in early-onset familial Alzheimer's disease. Nature 1995, 375:754-760.

97. Swerdlow RH: Pathogenesis of Alzheimer's disease. Clin Interv Aging 2007 2:347-359.

98. Swerdlow RH, Burns JM, Khan SM: The Alzheimer's disease mitochondrial cascade hypothesis: progress and perspectives. Biochim Biophys Acto 2013, S0925-4439:00289-5.

99. Swerdlow RH, Khan SM: A "mitochondrial cascade hypothesis" for sporadic Alzheimer's disease. Med Hypotheses 2004, 63:8-20.

100. Piaceri I, Rinnoci V, Bagnoli S, Failli Y, Sorbi S: Mitochondria and Alzheimer's disease. J Neurol Sci 2012, 322:31-34.

101. Sorbi S, Bird ED, Blass JP: Decreased pyruvate dehydrogenase complex activity in Huntington and Alzheimer brain. Ann Neurol 1983, 13:72-78

102. Chandrasekaran K, Giordano T, Brady DR, Stoll J, Martin LJ, Rapoport SI: Impairment in mitochondrial cytochrome oxidase gene expression in Alzheimer disease. Brain Res Mol Brain Res 1994, 24:336-340.

103. Nixon RA: The calpains in aging and aging-related diseases Ageing Res Rev 2003, 2:407-418.

104. Kruman I, Guo Q, Mattson MP: Calcium and reactive oxygen species mediate staurosporine-induced mitochondrial dysfunction and apoptosis in PC12 cells. J Neurosci Res 1998, 51:293-308.

105. Knott AB, Perkins G, Schwarzenbacher R, Bossy-Wetzel E: Mitochondrial fragmentation in neurodegeneration. Nat Rev Neurosci 2008, 9:505-518.

106. Gu XM, Huang HC, Jiang ZF: Mitochondrial dysfunction and cellular metabolic deficiency in Alzheimer's disease. Neurosci Bull 2012, 28:631-640.

107. Jones AW, Yao Z, Vicencio JM, Karkucinska-Wieckowska A, Szabadkai G: PGC-1 family coactivators and cell fate: roles in cancer, neurodegeneration, cardiovascular disease and retrograde mitochondria-nucleus signalling. Mitochondrion 2012, 12:86-99.

108. Ciron C, Lengacher S, Dusonchet J, Aebischer P, Schneider BL: Sustained expression of PGC-1alpha in the rat nigrostriatal system selectively impairs dopaminergic function. Hum Mol Genet 2012, 21:1861-1876.

109. Garcia-Escudero V, Martin-Maestro P, Perry G, Avila J: Deconstructing mitochondrial dysfunction in Alzheimer disease. Oxid Med Cell Longev 2013, 2013:162152

110. Silva DF, Selfridge JE, Lu J, EL, Cardoso SM, Swerdlow RH: Mitochondrial abnormalities in Alzheimer's disease: possible targets for therapeutic intervention. Adv Pharmacol 2012, 64:83-126.

111. Montinaro M, Uberti D, Maccarinelli G, Bonini SA, Ferrari-Toninelli G, Memo M: Dietary zeolite supplementation reduces oxidative damage and 
plaque generation in the brain of an Alzheimer's disease mouse model. Life Sci 2013, 92:903-910.

112. Foolad F, Khodagholi F: Dietary supplementation with Salvia sahendica attenuates acetylcholinesterase activity and increases mitochondrial transcription factor $\mathrm{A}$ and antioxidant proteins in the hippocampus of amyloid beta-injected rats. J Pharm Pharmacol 2013, 65:1555-1562.

113. Dragicevic N, Delic V, Cao C, Copes N, Lin X, Mamcarz M, Wang L, Arendash GW, Bradshaw PC: Caffeine increases mitochondrial function and blocks melatonin signaling to mitochondria in Alzheimer's mice and cells. Neuropharmacology 2012, 63:1368-1379.

114. Navarro A, Gomez C, Lopez-Cepero JM, Boveris A: Beneficial effects of moderate exercise on mice aging: survival, behavior, oxidative stress, and mitochondrial electron transfer. Am J Physiol Regul Integr Comp Physiol 2004, 286:R505-511.

115. Steiner JL, Murphy EA, McClellan JL, Carmichael MD, Davis JM: Exercise training increases mitochondrial biogenesis in the brain. $J$ Appl Physiol 2011, 111:1066-1071.

116. Marques-Aleixo I, Oliveira PJ, Moreira PI, Magalhaes J, Ascensao A: Physical exercise as a possible strategy for brain protection: evidence from mitochondrial-mediated mechanisms. Prog Neurobiol 2012, 99:149-162.

117. Camilleri A, Zarb C, Caruana M, Ostermeier U, Ghio S, Hogen T, Schmidt F, Giese A, Vassallo N: Mitochondrial membrane permeabilisation by amyloid aggregates and protection by polyphenols. Biochim Biophys Acta 1828, 2013:2532-2543

118. Massudi H, Grant R, Braidy N, Guest J, Farnsworth B, Guillemin GJ: Age-associated changes in oxidative stress and NAD + metabolism in human tissue. Plos One 2012, 7:e42357.

119. Massudi H, Grant R, Guillemin GJ, Braidy N: NAD + metabolism and oxidative stress: the golden nucleotide on a crown of thorns. Redox Rep 2012, 17:28-46.

120. di Lisa F, Ziegler M: Pathophysiological relevance of mitochondria in NAD + metabolism. FEBS Lett 2001, 492:4-8.

121. Wang H, Schimoji M, Yu SW, Dawson TM, Dawson VL: Apoptosis inducing factor and PARP mediated injury in the MPTP mouse model of Parkinson's disease. Ann N Y Acad Sci 2003, 991:132-139.

122. Meyer R, Meyer-Ficca M, Jacobsen E, Jacobsen M: Enzymes in poly(ADP-Ribose) Metabolism. In Poly(ADP-Ribosyl)ation. Edited by Burkle A. New York: Springer-Landes Bioscience; 2006

123. Alano CC, Ying W, Swanson RA: Poly(ADP-ribose) polymerase-1 mediated cell death in astrocytes required NAD + depletion and mitochondrial permeability transition. J Biol Chem 2004, 279:18895-18902.

124. Braidy N, Poljak A, Grant R, Jayasena T, Mansour H, Chan-Ling T, Guillemin GJ, Smythe G, Sachdev P: Mapping NAD (+) metabolism in the brain of ageing Wistar rats: potential targets for influencing brain senescence. Biogerontology 2013, 15:177-98.

125. Ryan L: Update on Alzheimer's disease clinical trials. National Institutes on Aging (NIA), National Institutes on Health (NIH), on National Alzheimer's Coordinating Center (NACC), revised February 17th, 2014. https://www.alz. washington.edu/NONMEMBER/SPR12/Ryan.pdf.

126. Watson GS, Cholerton BA, Reger MA, Baker LD, Plymate SR, Asthana S, Fishel MA, Kulstad JJ, Green PS, Cook DG, Kahn SE, Keeling ML, Craft S: Preserved cognition in patients with early Alzheimer disease and amnestic mild cognitive impairment during treatment with rosiglitazone: a preliminary study. Am J Geriatr Psychiatry 2005, 13:950-958.

127. Risner ME, Saunders AM, Altman JF, Ormandy GC, Craft S, Foley IM, ZvartauHind ME, Hosford DA, Roses AD: Efficacy of rosiglitazone in a genetically defined population with mild-to-moderate Alzheimer's disease. Pharmacogenom J 2006, 6:246-254.

128. Heneka MT, Sastre M, Dumitrescu-Ozimek L, Hanke A, Dewachter I, Kuiperi C, O'Banion K, Klockgether T, Van Leuven F, Landreth GE: Acute treatment with the PPARgamma agonist pioglitazone and ibuprofen reduces glial inflammation and Abeta1-42 levels in APPV717l transgenic mice. Brain 2005, 128:1442-1453.

129. Jiang $Q$, Heneka M, Landreth GE: The role of peroxisome proliferatoractivated receptor-gamma (PPARY) in Alzheimer's disease: therapeutic implications. CNS Drugs 2008, 22:1-14.
130. Lincoff AM, Wolski K, Nicholls SJ, Nissen SE: Pioglitazone and risk of cardiovascular events in patients with type 2 diabetes mellitus: a meta-analysis of randomized trials. J Am Assoc Med 2007, 298:1180-1188

131. Geldmacher DS, Fritsch T, McClendon MJ, Landreth G: A randomized pilot clinical trial of the safety of pioglitazone in treatment of patients with Alzheimer disease. Arch Neurol 2011, 68:45-50.

doi:10.1186/1478-811X-12-23

Cite this article as: Godoy et al: Signaling pathway cross talk in Alzheimer's disease. Cell Communication and Signaling 2014 12:23.

\section{Submit your next manuscript to BioMed Central and take full advantage of:}

- Convenient online submission

- Thorough peer review

- No space constraints or color figure charges

- Immediate publication on acceptance

- Inclusion in PubMed, CAS, Scopus and Google Scholar

- Research which is freely available for redistribution

Submit your manuscript at www.biomedcentral.com/submit
C Biomed Central 